European Journal of Pragmatism and American Philosophy

VIII-1 | 2016

Dewey's Democracy and Education as a Source of and a Resource for European Educational Theory and Practice

\title{
Gestures Historical and Incomplete, Critical yet Friendly
}

\section{Vincent Colapietro}

\section{(2) OpenEdition}

\section{Journals}

Electronic version

URL: http://journals.openedition.org/ejpap/453

DOI: 10.4000/ejpap.453

ISSN: 2036-4091

\section{Publisher}

Associazione Pragma

\section{Electronic reference}

Vincent Colapietro, «Gestures Historical and Incomplete, Critical yet Friendly », European Journal of

Pragmatism and American Philosophy [Online], VIII-1 | 2016, Online since 20 July 2016, connection on 19 April 2019. URL : http://journals.openedition.org/ejpap/453 ; DOI : 10.4000/ejpap.453

This text was automatically generated on 19 April 2019

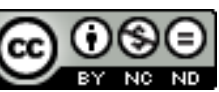

Author retains copyright and grants the European Journal of Pragmatism and American Philosophy right of first publication with the work simultaneously licensed under a Creative Commons AttributionNonCommercial-NoDerivatives 4.0 International License. 


\title{
Gestures Historical and Incomplete, Critical yet Friendly
}

\author{
Vincent Colapietro
}

"Thought requires achievement for its own development, and without this development it is nothing. Thought must live and grow in incessant new and higher translations, or it proves itself not to be genuine thought." - C. S. Peirce (CP 5.595)

\section{Introduction: Captivating Pictures and Liberating Gestures}

1 At the center of one of the most famous anecdotes involving a famous philosopher, we encounter what is commonly called in English a gesture, in fact, a Neapolitan gesture, though one made by a Turinese Jew at an English university. While gestures carry meaning $(9,69-70),{ }^{1}$ they are themselves carried across various borders, geographical, ethnic, cultural, linguistic, and otherwise. Unquestionably, they are readily portable carriers of various meanings, not least of all those bound up with a wide array of human judgments (ranging from contempt and disgust to solicitude and reverence). Whether or not the gesture to which I am alluding would count as one in Giovanni Maddalena's sense is questionable (a point to which I will return). ${ }^{2}$ But there is no dispute about how we would ordinarily identify the animated response by the Italian economist Piero Sraffa to Ludwig Wittgenstein's intransigent insistence regarding meaning necessarily being a function of logical form. For speakers of English at least, Sraffa's response is a gesture, indeed, the paradigm of such a communicative or expressive act. So, unlike the incident involving Wittgenstein's poker (Edmonds \& Eidinow; also Monk), that concerning Sraffa's gestural counterexample directed at Wittgenstein's adamantine position is enfolded in hardly any controversy. There is little doubt the incident occurred, even less what significance it carried for Wittgenstein. 
2 Even so, it is instructive to set this anecdote in context, especially since it proved to be truly pivotal. It is indeed the point around which Wittgenstein turned from his vision of language as put forth in his Tractatus Logico-Philosophicus to that defended in his Philosophical Investigation. Norman Malcolm pairs this story with another anecdote. According to the Tractarian account of propositions and hence (at least) this species of meaning, a proposition is a picture. It is not so much a pictorial representation as a logical picture, though the pictorial and the logical here might not be ultimately separable. Wittgenstein hit upon this idea "when he was serving in the Austrian army in the First [World] War" (Malcolm 2001: 68). ${ }^{3}$ As he told Malcolm and "several other persons," he read an account in a newspaper "that described the occurrence and location of an automobile accident by means of a diagram or map." Wittgenstein took this map to be not only a proposition but also one in which the essential nature of propositions was rendered perspicuous: a proposition is a picture of reality (Ibid.: 68-9).

The complementary anecdote is the one concerning how he came to abandon this picture of propositions, the one to which I alluded at the outset. As Malcolm recounts the story he heard directly from Wittgenstein, one day when

Wittgenstein was insisting that a proposition and what it describes must have the same 'logical form' Sraffa made a gesture, familiar to Neapolitans as meaning something like disgust or contempt, of brushing the underneath of his chin with an outward sweep of the finger-tips of one hand. And he asked: "What is the logical form of that?" Sraffa's example produced in Wittgenstein the feeling that there as an absurdity in the insistence [that the proposition must have the form of what it describes or represents]. (Ibid.: 69)

This broke the hold on him of a picture of what a proposition must be, indeed what language could only be. (Ibid: 69)

"A picture held us captive. And," Wittgenstein in his Philosophical Investigations adds, "we could not get outside it, for it lay in our language and language seemed to repeat it to us inexorably" (Wittgenstein 1968: §115). As it turns out, however, the picture of a picture and that of the proposition as a picture held Wittgenstein's own mind captive and Sraffa's gesture broke the hold of that picture.

What, if anything, holds Giovanni Maddalena's mind captive? If it can be shown that a picture or something else does arrest the movement of his thought, what gestures might I make that would work to loosen the hold of these unacknowledged metaphors and unavowed images? As H. S. Thayer notes, "often in the study of philosophic argument, it is illuminating to watch the use of metaphors and similes. For these serve not only as means of stating arguments; they sometimes operate, if unconsciously, to guide and help sustain the argument in question" (Thayer 1973: 44). Beyond this, they tend to underwrite historically contingent questions, making them appear to be inescapable or necessary. Indeed, they can appear so inescapable as to make historical contingencies appear to be ontological necessities. Part of the task of philosophy is, thus, to exhibit these contingencies for what they are, thereby freeing thought from vitiating fixations.

6 Here I join Giovanni Maddalena in his keen attention to such frequently ignored features of philosophical writings. But, above all else, this paper is an attempt to answer these two questions (What might be holding Giovanni's own mind captive? What gestures might in this connection prove liberating?) - nothing more, nothing, less. Ultimately, this means enacting a series of gestures, some perhaps sharply critical, by which we might loosen the grip of a certain picture of Peirce, also a certain understanding of the historical task of pragmatist philosophers after Kant's critical turn. However critical, these gestures are 
intended to be friendly. For Giovanni and I are truly joined in the communal endeavor of deepening philosophical understanding of phenomena, at once, utterly commonplace and deeply significant. In the first instance, we are struggling to discern what stares us in the face; in the second, to offer generalizations attuned to the richness of these phenomena (EP 2: 147-8).

\section{Completion v. Transfiguration}

7 Above all else, Immanuel Kant's critical project holds Giovanni Maddalena's historical imagination captive. In his judgment, the alternatives are either to abandon or to complete Kant's project (3). ${ }^{4}$ Might there however not be other alternatives (cf. Christensen)? Does, for example, G. W. F. Hegel abandon or complete Kant's project? Is not the most accurate response to the stark alternatives with which we are confronted: neither - or both! Hegel so radically transformed, by means of an immanent critique, the Kantian endeavor that orthodox Kantians are certainly justified in claiming that Hegel has changed the conversation. But Hegel might counter that the project cannot be completed on its own terms: those very terms require a radical transformation of any philosophical undertaking responsive to the definitive crises of late modernity. The framework is exploded by problems it cannot avoid addressing but cannot effectively address (e.g., the relationship between nature and freedom, that between heteronomy and autonomy, that between imagination and reason, and that between self and other). Hence, Hegel might also go on to insist that his achievement encompasses the completion of Kant's project in the only workable sense in which this project can be completed. For it decisively drives beyond Kant and it does so in the direction of history, experience, and concreteness. ${ }^{5}$ Building amid the ruins of such a framework, even while ineluctably using materials and incorporating aspects of the design from the structure previously embodied in these materials, does not commit those engaged in this task of replicating that design.

8 The experience of thinking over, yet again, what has been thought over by one's predecessors is as much an instance of experience as what we more commonly identified as experience (Russon 2015). The need to do so is, as often as not, inherent in experience itself: there is an experiential urgency to reflect upon some more or less determinate experience and, in the course of doing so, we frequently come to the realization that our inherited concepts provide inadequate resources for this creative task (Diamond). New tools need to be forged; new conceptions need to be fashioned, if we are going to come to terms with the experience in question. We might poor new wine into old bottles, but we would be less than wise to try pouring molten steel into glass containers. "We learn by experience," Hegel insists, "that we meant something other than we meant to mean; and this correction of our meaning compels us to go back to the proposition [in its original form or in our initial understanding], and understand it in some other way" (Hegel 1981: 39). Even the most radical innovations are continuous with their generative conditions. Such inevitable continuity does however not precluded truly radical innovation. I would accordingly insist here: Witness Hegel. Or, of greater, relevance: Witness Peirce vis-à-vis Kant, Schiller, and Hegel, on one side, Locke, Berkeley, and Reid, on the other.

of course, Maddalena might claim that his attempt to complete both Kant and Peirce's project entails transformation. On his account, to complete this project is to offer a truly synthetic approach to synthetic reasoning, that is, to break with the analytic paradigm 
and to offer a novel framework only hinted at by Peirce. In my judgment, however, this would be a reasonable but hardly adequate reply. First, the virtually exclusive focus on analysis and synthesis distorts our understanding of Peirce and, more generally, pragmatism. Second, the truly radical character of Peirce's philosophical project is missed. His preoccupation is with not the abstract possibility but the concrete growth of knowledge. In effect, he replaces epistemology with methodology (or, in his own words, methodeutic or speculative rhetoric, "the highest and most living branch of logic" (CP 2: 333; see Fisch 1986; Santaella 1999; and Bergman 2009). As envisioned by Peirce, the task is not to refute the skeptic, but to assist the growth of knowledge; not to demonstrate the abstract possibility of knowing something no one does or even can actually doubt, but to institute procedures by which concrete opportunities for facilitating paths of inquiry are seized. Third, the essentially historical and, thus, invincibly open-ended character of all human endeavors, including theoretical pursuits, tends also to be missed or, worse, occuled. Take one of Maddalena's paradigmatic instances of a "complete gesture" - the ritual of baptism. This ritual is a call to the community to assist in the difficult, delicate task of initiating a new being into a form of life. By its nature, it cannot be complete in itself: in inaugurates a historical task of an indefinitely ramifying nature. Its "beginning" is the self-conscious continuation of a living tradition, just as its "end" is the self-resolved commitment to take up a task for the indefinite future.

However this may be, Maddalena is certainly correct to claim, "one cannot understand pragmatism if one's anti-Cartesianism is not supplement by a profound anti-Kantianism" (28). But what I am urging is a much more profound anti-Kantianism than anything discernible in The Philosophy of Gesture. To be captivated by problems having their origin in the dualism of analysis and synthesis is not anti-Kantian enough.

11 This begins to become clear when we disentangle the hermeneutic and the philosophical aspects of Maddalena's undertaking. There is, first of all, the interpretive claim (Peirce falls short) and, then, the philosophical recommendation (we can complete what Peirce failed to complete by adopting a new paradigm of synthetic reasoning). The philosophical prescription is however dependent upon the hermeneutic diagnosis. If the diagnosis is erroneous, the prescription might be ineffective - or worse (for it might exacerbate rather than relieve the condition). On Maddalena's interpretation, we witness in Peirce's later thought a decisive drive toward some form "of complete syntheticity" (28). But, also on his interpretation, this drive stops short: Peirce is allegedly too deeply entangled in the Kantian framework to offer a completed form of synthetic rationality. This is part of a broader claim, one directed at not only a single figure in the pragmatist movement but also the entire movement. The pragmatists "never realized that their research pointed toward a complete synthetic pattern, where synthesis is achieved through synthetic tools" (30). Maddalena contends, "their tools remain an analytic way to approach synthetic reasoning" (Ibid.).

12 As an alternative, what I propose is this. What we need is a theory of inquiry based on our practices of inquiry and, hence, on the practical experience of expert inquirers but also merely competent and even simply novice ones. This would be a theory rooted in our experience of doubt but also our experience of overcoming doubt (conducting countless inquiries in an effective manner). Debates about the meaning of terms are idle or worse if they are not linked to the preoccupations of practitioners. The clarification of terms by an inquirer, for the sake of inquiry, is one thing. The definition of terms at the highest level of generality (e.g. What is knowledge? Or What is art?), with little or no regard for 
the exigencies of practice (and here this signifies the practice of inquiry) is quite another. Methodology in the Peircean sense would replace epistemology in its traditional sense (Ransdell 2000).

13 I offer these reflections and, above all, my criticisms as a gesture of friendship to one whose work I deeply admire. However they are defined, gestures do indeed carry meaning $(9,69-70)$. At the heart of any general theory of signs, there is a synecdoche or cluster of such figures of speech. At the center of Maddalena's purportedly pragmatist reconstruction (or "completion") of the Peirce project, there is the figuration of the gesture. Gestures by their very nature however are interpretants and objects, for they are generated and generated: they are in one respect the offspring of signs and, in another, the parent of signs, gestural and otherwise. Like all other signs, gestures are invincibly in complete. Closure is always perspectival and precarious, for it is at bottom the formation of a habit more fully and finely attuned to the dispositions of those agents and object that we encounter in experience.

"Peirce's progressive shift from Kant to Hegel" (42) was truly a decisive shift, a fateful rupture (hence, decidedly not an absolute breach). Among other things, it was a turn toward concrete forms of historical experience, thus, a turn away from formalist presuppositions (above all, away from those presuppositions in conjunction with the framing of our questions).

Peirce was not endeavoring to give a pragmatist answer to a Kantian question. Much like Hegel, he was working toward articulating a pragmatist framework of philosophical query (Buchler 1955). While Peirce's undertaking no less than Hegel's is unimaginable apart from Kant's aspirations, efforts, and indeed achievements, it bursts the narrow confines of various inherited frameworks, the Kantian as much as any other.

\section{Gestures Commonplace and Otherwise}

Gestures are commonplace. In fact, they are ubiquitous. Not only are they commonplace, but our understanding of them is as well. For the most part, however, this understanding is tacit and situated, not explicit and abstract. Moreover, it is practical, not theoretical. There is nonetheless also such an understanding of gestures in general. That is, we immediately grasp the significance of someone extending a hand upon being introduced to us or the significance of a friend upon leaving turning around and waving an arm. But we also immediately grasp what such acts in general are. Quite apart from being able to define words or ideas in a formal, abstract manner, we often have an effective and, in many instances, a nuanced and subtle comprehension of their meaning. This shows itself in our ability to use these signs not only appropriately but also creatively. Peirce identifies this as the first grade of conceptual clarity. His recognition of this grade of clarity is, in effect, a rebuke of Socrates, at least as Socrates is portrayed in some of Plato's early and indeed other dialogues. In such works as the Euthyphro and the Republic, Socrates tries to show one or another interlocutor that that individual does not know the meaning of the words he is using, since he cannot provide a defensible definition of what almost always is a commonplace work. Socrates appears to take the inability to be able to provide a formal, abstract definition of these contested words as a sign of ignorance, but virtually always unavowed ignorance (indeed, ignorance strenuously "denied"). In contrast, Peirce is valorizing our tacit, situated understanding of commonplace terms. Our ability to use them effectively and, of even greater import, creatively is an indication 
of our grasp of these terms. At the lowest level of clarity, then, we understand both what specific gestures signify and, beyond this, what gestures in general are.

This however does not mean that either the significance of specific gestures or that of gestures in general is simple or univocal. At both levels, our comprehension tends to be subtle and nuanced. Indeed, it needs to be. Our tacit, situated understanding needs to be as flexible, variable, and mobile as are the shifts and shades of significance borne by gestures. In other words, this tacit understanding operates in real time and, as a consequence, a sense of timing (that is, a sense of kairos (Smith 1969)) is characteristically displayed by not only the utterer but also the interpreter. Silence is hardly univocal. So, too, the significance of a smile can only be ascertained in situ. A seemingly simple expression turns out to be one capable of carrying widely variable meanings. There are, after all, smiles of refined contempt and ones of spontaneous joy, smiles of bemusement tinged with beneficent indifference and ones of acknowledgment animated by deep identification with another sentient being (Is it truly absurd to smile at a dog who is a companion?).

For the most part, then, our commonplace understanding of gesture operates on the first grade of clarity. For various purposes, however, we might feel compelled to fashion a formal, abstract definition of gesture. The relationship between our commonplace understanding and these theoretical formalizations is hardly straightforward. On the one hand, we can accord our everyday sense such authority that the very attempt to provide an abstract definition comes to be seen as an utterly futile undertaking. On the other hand, we can possess such confidence in our ability to fashion a completely general definition that we ride roughshod over the subtle distinctions embedded in ordinary language (Austin 1990). As Peirce insists, we cannot improve a language unless we reverence it. ${ }^{6}$ And we show our reverence for a language by painstakingly attending to the unpretentious genius embodied in our linguistic inheritance, not least of all by sharply focusing on the more or less implicit distinctions and affinities to which a language bears witness. At the most general level, language is logos or an indispensable instrument of that Protean power, for it enables us to gather together what is seemingly disparate but also to set off from one another things apparently identical. Our ability to distinguish this from that is of a piece with our ability to see this as an instance of that (e.g., to conceive a smile as an instance of a gesture and, at a higher level of generality, to conceive a gesture as a genre of actions). Out inability to distinguish this from that means that, in our understanding, they are indistinctly fused together: that is, they are confused. Our inability to ascertain affinities (e.g., our failure to discern that a whale is a mammal) entails that we are completely blind to countless connections and the implications flowing from our discovery of these connections. ${ }^{7}$

Maddalena proposes to offer an abstract definition of gesture rather than first attending to the tacit meanings carried by this commonplace word. More precisely and fairly, he offers such a definition after all too hurriedly canvassing the tacit meanings embedded in everyday language. Even so, one gets the sense - at least, I get the sense - that his efforts are informed by a felt sense for the tacit richness of quotidian words.

20 At least formally, his utterances indicate a commitment to pragmatism. (In truth, his commitment is more than formal, but I want to press this point as strong as possible, since I take this tendency to be far too prevalent among expositors and advocates of Peirce, not simply Giovanni.) This is nowhere more apparent than in his contention that, "we can say we clarify something when we transform our vague, familiar comprehension 
into a habit of action, not when we have a good definition" (70). There is however an irony here. While Maddalena formally acknowledges pragmatic clarification as the highest level of conceptual clarity, he practically operates for the most part on the intermediate level of abstract definition. The irony is even greater when we note that, in the passage just quoted, abstract definition is slighted by Maddalena. For Peirce at least, abstract definition is a crucial tool for conceptual clarification. To rest content with the results attained by means of this tool would, in effect, amount to arresting thought. Even so, pragmatic clarification massively draws upon the tacit understanding of "practical" familiarity ${ }^{8}$ but also critically depends upon the explicit formalizations provided by abstract definitions. We clarify something by defining it abstractly and by translating it pragmatically into habits of action. While formal, abstract definitions are often necessary tools to advance the business of inquiry, they are, in Peirce's judgment at least, never sufficient ones. But to say we need to go beyond them does not imply that we can dispense with them. ${ }^{9}$

In its most basic sense, Maddalena suggests that a gesture "is any performed act with a beginning and an end that carries a meaning (from gero = I carry on)" (69-70). But he is clear that this is not the sense with which he is principally preoccupied in his book: "we are not just seeking any gesture. Some gestures are only reactions. All gestures carry meaning, but they do not necessarily serve to recognize an identity fully" (70). ${ }^{10}$ Complete gestures, as Maddalena identifies them, are here tasked with a Herculean labor: they have as their function nothing less than the full recognition of what has proven to be for vast stretches of human history an elusive identity (e.g., the identity of identity itself, what we pragmatically mean by the identity of, say, a human person [see Maddalena, Chapter 6] or the identity of the divine or, more mundanely, that of words). Complete gestures are, in brief, tasked with full recognition of those historically elusive identities

Though he tends to use the adjective complete, Maddalena also employs perfect in conjunction with gestures. He is explicit about their equivalence: "here 'perfect' and 'complete' are actually synonymous" (70). For this and other reasons, it is instructive to compare Maddalena's conception of a perfect (or complete) gesture with Peirce's description of a "perfect sign." Given the importance of this comparison, also given how little attention is paid to Peirce's description of such signs, I will quote one of the most relevant texts at rather great length. In MS 283, Peirce characterizes "an ordinary conversation" as "a wonderfully perfect kind of sign-functioning" (EP 2: 391). He takes pains to explain what he means by a "perfect sign" (MS 283: 279-83; EP 2: note 25). He does so by asking us to consider "the aggregate formed by a sign and all the signs which its occurrence carries with it." In doing so we come to realize:

This aggregate will itself be a sign; and we may call it a perfect sign, in the sense that it involves the present existence of no other sign except such as are ingredients of itself. Now no perfect sign is in a statical [or inert] condition; you might as well suppose a portion of matter to remain at rest during a thousandth of a second, or any other long interval of time. The only signs which are tolerably fixed [and thus static or steadfast] are non-existent abstractions. We cannot deny that such a sign is real [as distinct from existent or actual]; only its mode of reality [or being] is not that active kind which we call existence. The existent acts, and whatsoever acts changes [by virtue of acting]...

- Every real ingredient of the perfect sign is aging, its energy of action upon the interpretant is running low, its sharp edges are wearing down, its outlines becoming more indefinite.

- On the other hand, the perfect sign is being perpetually acted upon by its object, 
from which it is perpetually receiving the accretions of new signs, which bring it fresh energy, and also kindle energy that it already had, but which had lain dormant.

- In addition, the perfect sign never ceases to undergo changes of the kind we rather drolly call spontaneous, that is, they happen sua sponte but not by its will. They are phenomena of growth.

- Such perfect sign is a quasi-mind. It is the sheet of "Existential Graphs"...

- This quasi-mind is an object which from whatever standpoint it be examined, must evidently have, like everything else, its special qualities of susceptibility to determination. Moreover, the determinations come as events each one once for all and never again. Furthermore, it must have its rules or laws, the more special [or specific] ones variable, others invariable.

This richly suggestive characterization of a perfect sign cannot be fully discussed here. For our purpose, we have the space only to highlight several salient traits of such signs and, then, only in a rather cursory manner. First, the materiality of any actual sign entails that the sign is in a sense aging. Second, the inherent dynamism of any sign is of such a nature that it points to the possibility of indefinite rejuvenation. This is most evident in the ability of the sign to be acted upon, however indirectly or mediately, by its object. Third, this dynamism also means that the sign is not only ceaselessly but also spontaneously changing. Fourth and finally, the growth of meaning is, among other things, a process of determination, one wherein the sign is becoming less vague, general, or both in some respects (while quite possibly also becoming indeterminate - more vague, general, or both - in other respects). Paradoxically, a perfect sign is, in other words, perfect by virtue of its imperfections, what alone makes possible its perfectability. Absolute perfection is in a pragmatist universe an ontological impossibility, whereas indefinite perfectability is the only tenable form of the highest good. Signs, at least as instruments of reasons, partake of the nature of reason: "the essence of Reason is such that its being can never have been completely perfected. It always must be," Peirce insists, "in a state of incipiency, of growth" (CP 1: 615). Nothing but the ceaseless growth of concrete reasonable can be made into the summum bonum. For example, consider the constitution of a country. A perfect constitution would be one in which its inescapable imperfections were formally acknowledged by building into its very structure procedures by which it can be amended, that is, made better (or more perfect) than it actually is. As such, it would make a virtue of a necessity - its historicity.

Let us return briefly to Peirce's example of a "perfect sign" - "an ordinary conversation." What makes this species of sign-functioning or semiosis worthy of such a designation? Its imperfections are likely to come to light in its prolongation. The objects under consideration are, through the mediation of the interlocutors, bringing to bear their weight on the development of their signs, however much the limitations and indeed biases of these interlocutors might distort and conceal various features of the dynamic object. In sum, perfect signs in the Peircean sense cannot be complete or perfect. In contrast, complete or perfect gestures in Giovanni's sense apparently can attain a form of closure Peirce would find impossible for any instance of semiosis to attain. Should we use Peirce's notion of semiosis to illuminate what Giovanni intends by gesture or rather should we use Giovanni's conception gesture to throw light on what Peirce identifies as semiosis? My own leaning should already be clear. In fairness, however, let us return to a more direct engagement with Giovanni Maddalena's innovative proposal. 


\section{Commonplaces Gestural and Otherwise}

Chapters 6 through 8 of The Philosophy of Gesture are devoted to the topics of identity, writing, morality, and education. Maddalena does not intend them to be merely illustrative of his suggestive notion of a complete gesture. Rather he turns to these topics to display the heuristic power of the new tool he has crafted principally in Chapters 3 though 5. At the conclusion of "How to Make Our Ideas Clear," Peirce turns to hardness, weight, force, and reality as phenomena calling for pragmatic clarification. No matter how perfect are our abstract definitions of these diverse phenomena, as abstract definitions, they are not sufficient. We must break out of the circle of words (cf. Short 2007). Defining one word in terms of others unquestionably has its value. But it also has its limitations, especially for anyone resolutely committed to experimental inquiry. Accordingly, we must break out of the circle of words immerse ourselves in the spirals of experience (Colapietro 2016). Such immersion involves striving to attune our habits more finely and fully to the habits of the beings we encounter in experience. More cautiously put, such immersion encourages us to strive to accomplish this.

The scope of this essay, alas, does not allow me to go into the details of Maddalena's treatment of the topics taken up in Chapters 6 through 8. I have taken this occasion to focus almost exclusively on what I take to be the heart of the matter, his ingenious proposal (his new paradigm of reasoning and, inextricably interwoven into this paradigm, his new tool of synthesis). If I judge this project to be a failure on its own terms (though this characterization needs to be qualified), if I take the proposal of this paradigm to be most superfluous, that is not as harsh a judgment as it will almost strike most readers. In rendering this judgment, indeed, I stand to Giovanni Maddalena precisely as he stands to Peirce. There is, in his critique of Peirce and, based upon it, his effort to go beyond his predecessor - his endeavor to bring to completion what Peirce failed to accomplish unmistakable respect for Peirce's stunning achievements. Failure in a significant respect, even in a definitive way, hardly precludes success in other respects, often ones of the utmost importance. Such success warrants admiration, but, then, so too do certain instances of "failure."

However it might be with complete gestures in Giovanni's sense, human endeavors are inevitably incomplete. Of course, one might respond to this claim by asserting there is incompleteness and incompleteness. For example, one might set out to solve a problem and leave it unsolved in the main, not merely in this or that detail. Even so, one's monumental failure might be more instructive than the minor successes of others. Marx would take this to be true of Hegel in comparison with numerous other thinkers who were more successful in either bringing to completion their own task or comprehending the nature of their endeavor. He deemed it as essential to work through the logic of Hegel's errors as to appropriate the insights of his predecessor. Indeed, the appropriation of such insights required him to work through the logic of these errors. One could not have the former without undertaking the later. Analogously, Maddalena seems to be working through Peirce's failures as a way of completing Peirce's project. But, then, I too am assumed a task akin to this, only with respect to Giovanni Maddalena himself. This however brings up the question of dealing with him on his own terms. An immanent critique can often be a radical critique, one in which the very terms of the controversy

European Journal of Pragmatism and American Philosophy, VIII-1 | 2016 
are profoundly altered. Hence, the very formulation of the questions is dramatically modified. (or carried forward) is not the direction to which Maddalena calls our attention. What we need most of all is a more thickly pragmatist description of experimental intelligence, hence a more fully pluralist portrait. This would encompass a more synechistic approach, but one along the lines already indicated by Peirce's experiments in formalization (e.g., his "Existential Graphs") and also by his pragmatist account of experimental inquiry.

\section{Conclusion}

A picture captivated Peirce, but did not hold him completely captive. It was the dramatic figure of experimental intelligence principally engaged in the passionate pursuit of novel truths, especially as this pursuit was exemplified by such sciences as physics, chemistry, astronomy, and biology. The Peircean portrait of this arresting figure is, alas, incomplete. What Giovanni Maddalena suggests in the later Chapters of this richly suggestive book is very helpful for how to sketch more fully the portrait of this figure.

European Journal of Pragmatism and American Philosophy, VIII-1 | 2016 

controversially) a creative appropriation of a classical notion, for Peirce's account of such intelligence is arguably a reworking of Logos, the capacity to gather together what is apparently disparate but also to distinguish what seems essentially identical. Finally, it is a self-consciously historical and communal project. For it concerns affective identification with historically evolved and evolving communities of self-critical inquirers. As such, it must be invincibly open-ended. While the language of closure in a guarded sense might be appropriate here, that of completion in any robust sense is always out of place. my head ever so slightly to my left, suppressing the faintest trace of a skeptical smile. My friend perceives my gesture as astutely as if I had shouted a protest. "Hide your thoughts! - Hide the sun and the moon. They publish themselves," Emerson insists, "to the universe" (quoted by James in McDermott 1978). We subsequently exchange a series of nuanced and subtle facial expressions, however compressed, before either one of us speaks. In the case of Giovanni Maddalena, his brow will often slightly knit, then a smile will ascend from his jaw to his eyes. The Italian face is remarkably adept as a canvas for facial gestures, so my description of a smile beginning beneath the lips and mouth is phenomenologically accurate! To be sure, it is no mean feat to have a smile begin with one's jaw. But, then, the human face possesses an irrepressible talent at self-portraiture. The serious point is that our gestures and other signs can carry the meanings of this exchange forward to the point that we reach a deep accord. The conversation is concluded rather than merely interrupted or broken off. But subsequent experience and the experientially rooted reflections on the ongoing course of our situated encounters force us, time and again, to think over what has been considered carefully a number of times.

The cumulative habits of ingenious actors equip these agents with the resources for extemporaneous responses to unexpected turns in a conversation or in the course of experience. Our intelligence and world are of such a character that the exercise of experimental intelligence in the contexts of historical circumstances inevitably get us into trouble, sooner or later. We are thrust by the very exercise of such intelligence into a world for which our intellectual inheritance, at bottom our sanctioned habits, is a hindrance as much as an aid. The very identification of the problems with which we are confronted depends upon theoretical creativity. Our insistence upon framing the problems with which we are wrestling in traditional terms is, indeed, part of the problem. Hence, part of the solution is to disentangle us from these terms. As often as not, this means freeing ourselves from certain pictures (e.g., the metaphor of foundations and, inseparably tied to this, that of knowledge as an edifice). We effectively miss the historical moment in which we are caught up. The force of experience demands us to consider candidly what we meant to mean (cf. Hegel 1981).

Peirce is one of the most paradoxical of philosophers precisely because he did not miss the singular character of his own historical moment, while being deeply appreciative of the abiding relevance of the dusty folios of the medieval schoolmen and the even more distant writings of classical thinkers. To some degree, all human self-understanding is however a case of misunderstanding. Peirce did not know quite what he was doing, but he was in this regard no different from any other human agent. The frustrating elusiveness 
of genuine continuity partly explains this failure, if an inevitable misunderstanding can properly be called a failure.

Giovanni Maddalena's The Philosophy of Gesture is itself an incomplete account of Peirce's various shortcomings in rendering more self-critical and self-conscious the ongoing task of philosophical inquiry. After Descartes but especially after Kant, the reflexive turn is integral to the responsible execution of this historical task. But the pragmatic turn saves the reflexive stance from degenerating into abstract universality and empty formalism (Smith 1992: Ch. 5). We can trace Sraffa's gesture to the rough-and-tumble world of Naples, just as we can ascertain the power of this gesture in the capacity of his fingers being brushed under his chin with an outward sweep to dissolve Wittgenstein's intransigence. In the wave of a hand, there can be magic. A world opens. Impasses and aporias are, in hindsight, spells cast over us by our complicity in allowing some fatal confusion or obscurity to ensnare us. More often than not, pictures are part of this.

To return to a point already anticipated, the question of how to conduct an inquiry replaces the question of whether our efforts at inquiry could ever be successful. In brief, methodology replaces epistemology, but so too does phenomenology replace metaphysics as first philosophy. Those committed to formulating a theory of semiosis (Fisch 1986; and Short 2007) might moreover properly resist allowing this theory to be subsumed under a philosophy of gesture. The general theory of signs fails essentially if it does not encompass a philosophical account of gesture. It is doubtful whether the philosophy of gesture can carry the weight put upon it by Giovanni Maddalena. More precisely, it is questionable whether either his conception of gesture truly captures Peirce's notion of semiosis or this conception can perform all the tasks to which it is being put. A pragmatist approach to synthetic processes, including rational deliberation, must be more than a synthetic approach. It must also be historicist as well as phenomenological, synechistic, pragmaticistic, normative, and ontological. Giovanni Maddalena does much to illuminate most of these facets. ${ }^{12} \mathrm{He}$ rather than Peirce - or, more accurately, along with Peirce - misunderstands the nature of his own undertaking. Peirce did not so much fail to complete his project as he failed to envision its scope. The distinctive form of experimental intelligence on display in the history of natural science hardly exhausts the expansive reach of this incomparable capacity. The histories of moral reflection, artistic endeavor, religious worship, political struggles, erotic engagements, and much else provide invaluable clues for our portrait gallery of the more striking members of a vastly extended family. These distinctive forms of experimental intelligence are, in other words, integral parts of an indeliminable continuum, making each of these forms themselves instances of continuity.

More than anything else, our thought needs to be made more dialogical. One of the most important ways of accomplishing this is by working to acknowledge the respects in which it already is dialogical, the depth to which it has been formed in a give-and-take with nothing less than reality. The "synthesis" that renders our thinking truly synthetic is that which makes our thinking more vitally and dramatically dialogical. The perfect sign is perfect only insofar as it possesses within itself the resources for its self-correction. Almost always, such self-correction takes the form of self-transformation. Consider the transformations of our understanding of energy or force in the history of our explorations of the forms of movement in which we are enmeshed.

The power of Peirce's Existential Graphs resides, at bottom, not in their formalization of a process but in the character of that process. The quasi-interpreter is called by the process 
itself to respond to the quasi-utterer (cf. Pietarinen 2006). What gestures of inclusion, exclusion, and transformation the quasi-interpreter makes in response to the inaugural gestures of the quasi-utterer determine the drama of self-correction and, hence, selftransformation. These Graphs enable to formalize certain steps in a process of ampliative reasoning and, as a result, enable to identify where we might have taken a misstep. They are tools of self-criticism and self-correction.

In sum, Peirce was not striving to complete Kant's project. Rather he was endeavoring to transform theoretical rationality into a deliberate capacity, hence one dependent on dramatic imagination and dialogical ingenuity. On this account, as Giovanni Maddalena notes, theoria becomes itself an instance of phronesis. This involves a fuller recovery of one part of Aristotle conjoined to a partial rejection of another part. Moreover, it marks a decisive break with Kant's critical philosophy, along with a surprising alliance with Hegel's profound insights, above all, his deeply penetrating insights into the critical role of the experience in carrying out the work of philosophy. Finally, it encompasses a vision of semiosis as dialogue (cf. Ransdell 1976) and, in turn, a vision of dialogue as revelatory of nothing less than the character of reality. That "most wonderfully perfect kind of signfunctioning" is perfect only in that its imperfections are destined to be disclosed in the fullness of time. In the meantime, the only time available to finite, fallible agents such as we are, we are tasked with assisting the growth of signs. For this, we need very often to suspend the dictates of cold justice and to follow the promptings of cherishing love (EP 1: $354)$.

My greatest fear is that, in this engagement with a dear friend's book, I have obeyed these dictates and failed to follow these promptings. In such an engagement, the all too likely result of cold justice is a deep injustice. Not only is a cognate of philia the prefix to the word philosophy but also philia is a word in its own right, designating a form of love at which distinct, yet inseparable, from the love of wisdom. For most of us, philosophical inquiry is not a solitary mediation (however many hours of private thought are consumed by a passionate commitment to philosophical reflection), but a communal undertaking. More often than not, it is an undertaking conjoining us to individuals with whom we have deep attachments.

The human face of "synthetic reason" is, accordingly, a spirited exchange in which the participants are mutually encouraging one another to follow the argument wherever it leads. In the course of such a conversation, we are not infrequently transformed. Our entrance is inevitably tardy (the conversation has been going on long before we arrive on the scene) and our exit tragically premature. ${ }^{13}$ Improvised and incomplete gestures are the best we can do. They characteristically draw upon a vast inheritance, are extemporized in a dramatic present, and drive toward an uncertain future. In a word, they are historical. For some purposes, these gestures can be conceived as having a determinate beginning and an equally determinate end, moreover, exhibiting the singular acts by which the gestures are made, the developmental teleology being served, consciously or not, by the gesturer, the densely blended character of any gesture, and indeed much else.

For the defining purposes of Peircean pragmatism, however, they are historical interventions in an ongoing flow of "perfect signs." The perfection of such signs resides in their perfectibility and, in turn, this perfectibility resides in the ways such signs serve as instruments of self-correction. In other words, the perfection of perfect signs in the Peircean sense is their continual exposure to radical transformation by the experiential 
realities to which they are responding by generating diverse yet interwoven series of interpretants (cf. 44).

The only synthetic unity ultimately needed is not anything as lofty as the transcendental unity of apperception. It is only the lowly question, "Don't you think so?" (MS 636: 26; quoted at 13). This simple question allows us to gather what we have been discussing and debating into an explicitly critical focus, but the focus of what can never be anything other than an open-ended exchange. Moreover, it concerns not the formal, abstract possibility of "I think" accompanying any one of my representations, but the situated, concrete need to appeal to the other. It is, in other words, exemplary of tuism ${ }^{14}$ - "Don't you think so?" or, in a less loaded form, "What do you think of this?" And it seems especially appropriate to conclude this critical engagement with Giovanni Maddalena's important book with just this interrogative gesture. This much is certain: what he thinks - how in particular he responds - will carry forward the open-ended task of self-critical inquiry, without any presumption of attaining completion or even approximating consensus. In conclusion, then, this "Reader Loquitur" (see, e.g., MS 598) ) $^{15}$ asks of the author of The Philosophy of Gesture, "Your thoughts?"

\section{BIBLIOGRAPHY}

AUSTIN J. L., (1990), Philosophical Papers, edited by J. O. Urmson \& G. J. Warnock, Oxford, Clarendon Press.

BERGMAn M., (2009), Peirce's Philosophy of Gesture, London, Continuum.

BERNSTEIN R. J., (1971), Praxis and Action, Philadelphia, University of Pennsylvania Press.

BERNSTEIN R. J., (2010), The Pragmatic Turn, Cambridge, Polity Press.

BUCZNYSKA-GAREWICZ H., (2007), "Sign and Dialogue," The American Journal of Semiotics, 2, 1/2, 27-43.

BURKE K., (1941), The Philosophy of Literary Forms. Studies in Symbolic Action, Baton Rouge, Louisiana State University Press.

BUCHLER J., (1955), Experience and Judgment, New York, Columbia University Press.

CALCATERRA R., (2003), Pragmatismo: i valori dell'esperienza, Roma, Carocci.

CHRistensen C. B., (1994), “Peirce's Transformation of Kant,” The Review of Metaphysics, 48, 1, 91-120.

COlAPIETRo V., (1989), Peirce's Approach to Self, Albany, NY, SUNY Press.

colapietro V., (2013), “Telling Tales Out of School: Pragmatic Reflections on Philosophical Storytelling," JSP, 27, 1, 1-32.

colapietro V., (2016), “The Pragmatic Spiral,” in Relational Hermeneutics, edited by Paul Fairfield.

DE JORIO A., (2001), Gesture in Naples and Gesture in Classical Antiquity, Bloomington, IN, Indiana

University Press. 
DEWEY J., (1988 [1922]), Human Nature and Conduct. The Middle Works of John Dewey, volume 14, edited by J. A. Boydston, Carbondale, IL, SIU Press.

DiAMOND C., (1988), “Losing Your Concepts,” Ethics, 98, 2, 255-77.

Eco U., (1994), The Limits of Interpretation, Bloomington, Indiana University Press.

EDMONDS D., \& J. EIDINOW, (2002), Wittgenstein's Poker: The Story of a Ten-Minute Argument between Two Great Philosophers, NY, Harper Perennial.

EMERSON R. W., (1985), R. W. Emerson: Selected Essays, edited by Larzer Ziff, NY, Penguin Books.

FISCH M. H., (1986), Peirce, Semeiotic, and Pragmatism: Essays by Max H. Fisch, edited by Kenneth Laine Ketner \& Christian J. W. Kloesel, Bloomington, Indiana University Press.

GAVA G., (2014), Peirce's Account of Purposeiveness: A Kantian Perspective, Routledge.

HEGEL G. W. F., (1981), The Phenomenology of Spirit, transl. A. V. Miller, Oxford, Oxford University Press.

JAMES W., (1975a), Pragmatism, Cambridge, Harvard University Press.

JAMES W., (1975b), The Meaning of Truth, Cambridge, Harvard University Press.

KANT I., (1965), The Critique of Pure Reason, transl. Norman Kemp Smith, New York, St. Martin's Press.

KETNER K. L., (1983), "Introduction" to "A Brief Intellectual Autobiography by Charles Sanders Peirce," The American Journal of Semiotics, 2, 1/2, 61-83.

MAdDalena G., (2015), The Philosophy of Gesture, Montreal, McGill-Queens Press.

MCDERMOTT J. J., (ed.), (1978), The Writings of William James: A Comprehensive Edition, Chicago: University of Chicago Press.

MALColm N., (2001), Ludwig Wittgenstein: A Memoir, Oxford, Oxford University Press.

MONK R., (1991), Ludwig Wittgenstein: The Duty of Genius, New York, Penguin Books.

ORTEGA José y Gasset, (1957), Man and People, transl. Willard D. Trask, New York, W. W. Norton \& Co.

PARKER K., (1998), The Continuity of Peirce's Thought, Nashville, TN, Vanderbilt University Press.

PEIRCE C. S., (1931), The Collected Papers of Charles Sanders Peirce, volume 1, edited by Charles Hartshorne \& Paul Weiss, Belknap Press of Harvard University Press. Cited as CP 1.

PEIRCE C. S., (1978), Charles Sanders Peirce: Contributions to the Nation, Part Two (1894-1900), edited by Kenneth Laine Ketner \& James Edward Cook, Lubbock, TX, Texas Tech University. Cited as CN II.

PEIRCE C. S., (1982), Writings of Charles S. Peirce: A Chronological Edition, Bloomington, University of Indiana Press. Cited as W 1.

PEIRCE C. S., (1992), The Essential Peirce, volume 1, edited by Nathan Houser \& Christian Kloesel, Bloomington, Indiana University Press. Cited as EP 1.

PEIRCE C. S., (1998), The Essential Peirce, volume 2, edited by Peirce Edition Project, Bloomington, IN, Indiana University Press. Cited as EP 2.

PERLOFF M., (1999), Wittgenstein's Ladder: Poetic Language and the Strangeness of the Ordinary, Chicago, University of Chicago Press. 
PIETARINEN A.-V., (2006), Signs of Logic: Peircean Themes on the Philosophy of Language, Games, and Communication, Dordrecht, Springer.

RANSDELL J., (1976), “Another Interpretation of Peirce's Semiotic,” Transactions of the Charles S.

Peirce Society, 12, 2, 97-110

RANSDell J., (2000), "Peirce and the Socratic Tradition," Transactions of the Charles S. Peirce Society, $36,3,341-56$

RUSSON J., (2015), Infinite Phenomenology: Lessons of Hegel's Science of Experience, Evanston, IL, Northwestern University Press.

SANTAELla L., (1999), “Methodeutics, the Liveliest Branch of Semiotics," Semiotica, 124, 3/4, 377-95.

SHORT T. L., (2007), Peirce's Theory of Signs, Cambridge, Cambridge University Press.

Smith J. E., (1969), “Time, Times, and the 'Right Time’: Chronos and Kairos,” The Monist, 53, 1, 1-13.

SMITH J. E., (1992), America's Philosophical Vision, Chicago, University of Chicago Press.

THAYER H. S., (1973), Meaning and Action: A Study of American Pragmatism, Indianapolis, BobbsMerrill Co.

WitTGENSTEIN L., (1968), The Philosophical Investigations, transl. G. E. M. Anscombe, New York, Macmillan.

ZALAMEA F., (2012), The Synthetic Philosophy of Contemporary Matemathics, New York, Urbanomics.

\section{NOTES}

1. All references, if not otherwise noted, will be to Maddalena 2015.

2. This essay has been at once exhilarating and difficult to write. Thinking through this richly suggestive text has been an exhilarating experience. Being critical of a dear friend in a public form has made the task a difficult one. What has greatly added to this difficulty is that I am far from confident that I sufficiently grasp either the main import or most critical details of this extremely subtle text (a text as suggestive and rich as it is subtle and, I must confess, elusive). The author has aptly chosen as his epigram a passage from Peirce: "Crystal clearness [...] is in philosophy the characteristic of second rates. The reason is that the strongest men are able to seize an all-important conception long before the progress of analysis has rendered it possible to free it from obscurities and difficulties" (CN II: 84). But this passage needs to be balanced by one from "How to Make Our Ideas Clear": "It is terrible to see how a single unclear idea, a single formula without meaning, lurking in a young man's head, will sometimes act like an obstruction of inert matter in an artery, hindering the nutrition of the brain" (EP 1: 127). I am certain that "complete gesture" is not a meaningless formula, but its meaning calls for a variety of analyses by which it can be, as far as possible, freed from difficulties and obscurities. My hope is that my own efforts contribute to this.

3. In Wittgenstein's Ladder (1991) Marjorie Perloff shows how the Tractatus needs - at least, invites - to be read in the context of war. The "sublime" vision of logic presented in that work (cf. Wittgenstein 1968: §§ 94-97) possesses its pathos and power only when set against the mundane experience of the soldier (also Monk). As far as he is from Wittgenstein, I wonder if Giovanni Maddalena's complete gesture is not in its way, however slightly, attached to a "sublime" logic. Are historical practices in their irreducible heterogeneity given their due by him, does he attempt at critical junctures to get back to the "rough ground" (Wittgenstein 1968: § 107) or rather does he work to ascend to an ideal level? 
4. James was emphatic: "The true line of philosophic progress lies, in short, it seems to me, not so much through Kant as round him to the point where now we stand" (James 1975a: 269). This is well known. Far less well known, however, was the mature Peirce's caustic disparagement of Kant's monumental book: he characterized the first Critique as "the very chimcera of the history of philosophy, according to the tongues of fame [...] but in reality nothing more portentous than a sickly little nanny-goat masquerading as a world-shatterer" (MS 609: 10; quoted in Fisch 1986: 257). While Peirce might have been led to Kant's critical project by Schiller's Aesthetic Letters, and while he might have devoted several early years to an intense study of the first Critique, the mature Peirce moved decisively beyond Kant. I am strongly disposed to think he did so by transforming what he took to be the task of philosophy. When late in his life he looked in the mirror of self-reflection, he has struck by his resemblance not to Kant but to Hegel (CP 1.42; and Colapietro 2013).

5. In The Meaning of Truth, James stresses: "The whole originality in pragmatism. The whole point in it, is its use of the concrete way of seeing. It begins with concreteness, and returns and ends with it" (James 1975b: 281-2). As it turns out, however, Hegel's critique of Kant's formalism is for the most part in the name of concreteness, just as Marx's critique of Hegel's "idealism" was. "How to make our philosophies concrete" is, for pragmatists and others, as urgent as "How to make are ideas clear."

6. In MS 279 ("The Basis of Pragmaticism," circa 1905), Peirce writes, "a language is a thing to be reverenced; and I protest that a man who does not reverence a given language is not in the proper frame of mind to undertake its improvements" (quoted in Colapietro 1989: 4). In this manuscript, Peirce argues that it is a great mistake to attempt reforming English by adopting German expressions out of harmony with it.

7. In Praxis and Action, Richard J. Bernstein suggests: "There is a descriptive, empirical, pragmatic temper manifested in Peirce's use of the categories. The 'proof' or, more accurately, the adequacy of the categories is to be found in the ways in which Peirce uses them to illuminate fundamental similarities and differences in everything we encounter" (Bernstein 1971: 178).

8. I am disposed to identify the first grade of conceptual clarity as "dumb smarts" because it is for the most part a linguistically tacit (or inarticulate) form of situated intelligence. In one respect, it is "dumb" or inarticulate (e.g., the experienced equestrian might not be able to express in words what she comprehends in and through her body when engaged while riding in the intricate exchange between herself and her horse). In another sense, however, it is remarkably intelligence and hence articulate. Intelligence is indeed by its very nature articulate, since it involves the capacity to draw distinctions and to draw from them implications - often in the blink of an eye. The slightest shift in the weight of the horse might to the experienced equestrian signal the imminent possibility an immense disaster. The subtle sounds discernible to the ears of the experienced mechanic would be another example of how the situated intelligence of the expert practitioner is definable in terms of articulation in some form. The deft, precise adjustments made by such a mechanic to the auditory clues emanating from the engine reveal that this individual's expertise resides in both knowing what different sounds mean and knowing how to respond effectively and differentially to the variable sounds. As William James notes in The Meaning of Truth, "you cannot keep hows and whats asunder" (James 1975b: 275; emphasis added), at least in the "universe of concrete facts."

9. As it turns out, however, this is a strategic question. Occasionally the insistent demand for abstract definitions is a heuristic impediment, not a methodological necessity. Moreover, the fixation on the crafting of such definitions can result in the increasing poverty of a discourse. For example, the extent to which epistemology becomes a quest for a formal, abstract definition of knowledge or aesthetics becomes a quest for such a definition of art, they have become impoverished fields, taking us away from the richness of our epistemic practices in the one case and that of our artistic contrivances in the other. 
10. The "only" here is troublesome, as is the word "reaction." If we replaced the word "reaction" with "response," I wonder if there would be any warrant for the word "only." Every gesture is a response and, as such, carries meaning by taking up - both by carrying forward and not infrequently by working against - trajectories of significance carried by the gestures and other phenomena to which the gesture is responding. In other words, gestures are always parts of a continuum and, as such, are themselves continuum. This renders problematic their origins and outcomes. For example, I respond to your gesture in this situation, but in fact in doing so I am picking up the thread of a conversation commenced long ago. We might also grab the other end of the stick. The death of a friend does not mark the end of our conversation with that individual. For instance, I can still vividly hear John E. Smith's voice, above all, in questions he would pose, objections he would raise, and qualifications he would insist upon. Without question, this is no substitute for his actual voice. But these auditory illusions are dialogical realities in which the power of the would-do and would-be here as everywhere else outstrips, in a certain sense, actuality.

11. In fairness to Giovanni Maddalena, his synthetic approach is to a great extent a synechistic approach. But rather than taking his contribution to be completing what Peirce allegedly failed to complete vis-à-vis Kant's project, I take him to be carrying forward what Peirce so dramatically exemplified - a synechistic approach to normative science and metaphysical inquiry, rooted in a phenomenological and indeed mathematical insights into continuity. When he draws explicitly on Fernando Zalamea's work on Peirce's concept of continuity (see especially Zalamea 2012: 50ff.), The Philosophy of Gesture gathers a power and focus it does not display when he is trying to show how Peirce needs to be assisted by the philosophical innovation of the complete gesture. He is in effect tracing out not only a distinctively Peircean trajectory but also in substantively Peircean terms. I have no question that Maddalena's philosophical innovation is an important one, though not for the purpose he has designed it!

12. Of these facets, he does the least justice to the temporal and, more narrowly, the historical features of the ongoing processes and practices falling with the scope of his concern, the most justice to the formally semiotic and irreducibly ontological features.

13. "Imagine," Kenneth Burke as us, "that you enter a parlor. You come late. When you arrive, others have long preceded you, and they are engaged in a heated discussion, a discussion too heated for them to pause and tell you exactly what it is about. In fact, the discussion has already begun long before any of them go there, so that no one present is qualified to retrace for you all the steps that had gone before. You listen for a while, until you decide that you have caught the tenor of the argument; then you put in your own oar. Someone answers. You answer him; another comes to your defense; another aligns himself against you, to either the embarrassment or gratification of your opponent, depending upon the quality of the ally's assistance. However, the discussion is interminable. The hour grows late, you must depart. And you do depart, with the discussion still vigorously in progress" (Burke 1941: 110-11; quoted in Bernstein 1971: 221, note 36$)$.

14. Tuism is a word Peirce apparent coined to name the "doctrine that all thought is addressed to a second person [a thou or tu], or to one's future self as a second person" (quoted in Max H. Fisch's Introduction to W 1).

15. Even the most charitable reader is, at some level, talking back to the text being interpreted, posing questions regarding the basic meaning of key terms and countless other matters. That is, even (perhaps especially) the most charitable interpreter must be, in Peirce's words, a "Reader Loquitur." 


\section{AUTHOR}

\section{VINCENT COLAPIETRO}

Pennsylvania State University

vxc5[at]psu.edu 